\title{
Economia social, economia solidária, terceiro setor: do que se trata?
}

\author{
Noëlle Marie Paule Lechat ${ }^{1}$
}

\section{Introdução}

Para analisar a literatura brasileira sobre a economia solidária é preciso um certo recuo. Se quisermos estranhar o familiar, nada melhor que situá-lo num conjunto teórico maior no qual suas particularidades vão sobressair-se por contraste, permitindo assim definir com mais rigor a sua identidade e originalidade. Com este propósito tentei saber como é tratada em outros países a questão em estudo. Lendo uma vasta bibliografia sobre economia social, economia solidária e terceiro setor, deparei-me com uma interrogação: a economia solidária faz parte do terceiro setor? A resposta a esta pergunta tem implicações teóricas e práticas. Se tiver entendido bem falas e escritos de certos estudiosos francófonos, e se minha interpretação estiver correta, a resposta é afirmativa. Mas, para os intelectuais brasileiros do que eu chamo campo da economia solidária, posso afirmar que a resposta é negativa, se bem que não a ponto de negar o vínculo existente entre os dois, pelo menos ao tratar-se de Gaiger (1996: 124 e 2000b), Dal Ri e Vieitez (1999), Sarria (2000) e Singer (2001). Se ela não fizer parte do ter-

${ }^{1}$ Doutoranda em Ciências Sociais na Unicamp, leciona antropologia na Unijuí. Endereço: noelle lechat@hotmail.com 
ceiro setor ou economia social ${ }^{2}$ - termo que prefiro em relação ao outro -, seu estudo no Brasil pode vir a ser uma ferramenta para a crítica da concepção de terceiro setor. Se ela o fizer, minha hipótese é que a falta desta visão panorâmica leva a uma imagem ingênua do lugar da economia solidária no conjunto da sociedade e no seu futuro.

A seguir, proponho-me a expor brevemente a origem dos conceitos e o problema da terminologia em diferentes países do mundo para, finalmente, confrontar as concepções a respeito do terceiro setor em geral e da economia solidária tal como é entendida no Brasil.

\section{A origem dos conceitos}

A primeira constatação é que a "nova literatura" existente no exterior sobre economia solidária é muito mais antiga do que a brasileira, iniciando não somente no mundo francófono na década de $1980,{ }^{3}$ mas também na América Latina e em particular no Chile, onde se desenvolveu especialmente graças a Luís Razeto. A Economia Social, segundo o historiador francês André Guélin, é um conceito que emerge no final do primeiro terço do século XIX como uma outra maneira de fazer da Economia Política (Guélin 1998: 1). Por que então dizer que os intelectuais produziram sobre este tema a partir dos anos 1980 do século XX se a economia social existe desde o século XIX, e se desde então sempre houve estudos na Europa sobre cooperativismo, associativismo e mutualismo? Há duas razões para isto.

Em primeiro lugar, a partir dos anos 1975-1976, são registrados fenômenos novos, provocados por uma série de mudanças principalmente de ordem econômica e cultural. Com a crise do sistema capitalista e suas conseqüências, o desemprego e o fechamento de empresas, criou-se um quadro dramático para a classe trabalhadora. Floresceu, então, a partir de 1977 e até 1984, uma série de

${ }^{2} \mathrm{O}$ termo é uma tradução do conceito francês Économie Sociale que foi assimilado a Third Sector (Terceiro Setor), apesar de não ser exatamente a mesma coisa, como explicarei a seguir. Infelizmente, no Brasil o termo Economia Social possui um significado distinto. É empregado para designar políticas públicas em áreas como educação, saúde e moradia popular.

${ }^{3}$ A este respeito, ler Boudet, que em 1985 publica um balanço das pesquisas sobre a vida associativa na revista Recma (Revue des études coopératives, mutualistes et associatives, fundada em 1921 e que tem por subtítulo: Revue internationale de l'économie sociale), Guélin (1998), Lévesque (1997) e outros. 
iniciativas para salvar ou criar empregos, através de empresas autogeridas pelos próprios trabalhadores, e isto com o apoio de alguns sindicatos progressistas. Entre 1980 e 1985, foram criadas em massa cooperativas de trabalhadores em toda a Europa (Defourny 2001). Por outro lado, os inúmeros movimentos sociais e étnicos trouxeram uma nova visão do social, da sua relação com o econômico e da relação do homem com o meio-ambiente. A queda do muro de Berlim, símbolo do fim de uma utopia, levou à produção de novas utopias compostas por comunitarismo, solidariedade e voluntarismo.

Em segundo lugar, numerosos pesquisadores, principalmente economistas e sociólogos, entusiasmados com esta nova realidade, produziram novas teorias para estudar tais fenômenos.

\section{Quais as terminologias usadas?}

Na França, segundo André Guélin, o rótulo de "économie sociale" é difícil de definir, pois durante um século e meio já serviu para referir-se a diversas realidades. É notável que no século XIX todas as tendências políticas embarcaram nesta nova proposta. Tanto socialistas (Pecqueur, Vidal, Malon) como social-cristãos (Le Play) e mesmo liberais (Dunoyer), sensibilizados com o custo humano da revolução industrial, criticaram a ciência econômica por não integrar a dimensão social.

Quanto à definição atual da economia social, segundo o mesmo autor, "ela é composta por organismos produtores de bens e serviços, colocados em condições jurídicas diversas no seio das quais, porém, a participação dos homens resulta de sua livre vontade, onde o poder não tem por origem a detenção do capital e onde a detenção do capital não fundamenta a aplicação dos lucros". (Guélin 1998: 13)

Em 1994, Laville caracterizava a economia solidária como um conjunto de atividades econômicas cuja lógica é distinta tanto da lógica do mercado capitalista quanto da lógica do estado. Ao contrário da economia capitalista, centrada sobre o capital a ser acumulado e que funciona a partir de relações competitivas tendo por objetivo o alcance de interesses individuais, a economia solidária organiza-se a partir de fatores humanos, favorecendo as relações onde o laço social é valorizado através da reciprocidade e adota formas comunitárias de propriedade. Ela distingue-se também da economia estatal que supõe uma autoridade 
central e formas de propriedade institucional (Laville 1994: 211). Mas ele nos previne que o deslocamento destas manifestações no tempo e no espaço - a primeira manifestação era pré-keynesiana e a atual corresponde à crise do compromisso keynesiano - aponta para os limites de uma conceituação da economia solidária em termos de terceiro setor.

Para Laville e Roustang (1999), o conceito de economia solidária proporciona uma ênfase sobre o desejo primeiro da economia social, na sua origem, de evitar o fosso entre o econômico, o social e o político, pois é na articulação destas três dimensões que se situa o essencial da economia social ou solidária. $\mathrm{O}$ termo, segundo esses autores, tenta dar conta da originalidade de numerosas iniciativas da sociedade civil que não se encaixam na trilogia legalizada na França das cooperativas, mutualidades ${ }^{4}$ e associações. Mas os autores alertam que o termo não é a expressão do que seria desejável fazer. Ele visa muito mais a problematizar práticas sociais implantadas localmente.

Para realidades como as dos países em desenvolvimento da África e da América Latina, diferentes das que existem nos países do Norte, o termo economia popular ${ }^{5}$ é preferido por autores como Nyssens (1996) e Larrachea que, neste caso, buscam inspiração em Luís Razeto. Segundo os autores, referindo-se ao caso de Santiago do Chile, este setor da economia é constituído pelo conjunto das atividades econômicas cujos atores fazem parte da população mais pobre da cidade (Larrachea e Nyssens 1994: 181).

Defourny et al. (1999) resumem assim as várias terminologias: a expressão terceiro setor, mesmo que imperfeita, é a que alcança maior consenso ao nível internacional. Como prova disto, citam a associação International Society for Third Sector Research, criada em 1992. Mas, observam eles, se olharmos para regiões geográficas específicas, outros termos são preferidos. Assim, nos EUA fala-se em non-profit sector ou independent sector, que corresponde à apelação inglesa de voluntary organizations. O termo economia solidária e a apelação organizaciones de economía popular são mais comuns na América Latina. ${ }^{6}$ Segun-

\footnotetext{
${ }^{4}$ Associações de ajuda mútua, principalmente na área da saúde.
}

${ }^{5}$ Este conceito já foi bastante discutido e recebeu críticas contundentes. Ver, p. ex.: Ceas (1994) e Singer (2000: 143-147).

${ }^{6}$ Pelo que conhecemos, com algumas ressalvas para Razeto, José Luis Coraggio e Orlando Núñez, na América Latina o termo economia solidária equivale ao de economia social. 
do Defourny (2001), na Alemanha usa-se a palavra Gemeinwirtschaft ${ }^{7}$ e na Suécia, folkrörelse ou association ideel.

Segundo os mesmos autores, duas apelações para o terceiro setor adquiriram uma vocação internacional, senão universal: a de economia social (ou solidária) e a de non-profit sector. ${ }^{8}$ Essas duas noções são também as que têm as bases teóricas mais firmes. A concepção de economia social é mais ampla, pois ao lado das associações sem fins lucrativos ela inclui um tipo de empresa: as cooperativas que, difundidas no mundo inteiro, encarnam, muitas vezes há mais de 150 anos, a busca de uma terceira via entre o capitalismo e o centralismo de Estado. Além disto, incorpora um outro tipo de organização, as mutualidades que, estando também muito presentes em vários países, desempenham ou vão desempenhar um papel central na organização da saúde e da previdência social. Assim, resumindo, o terceiro setor pode ser apresentado como constituído por três grandes componentes, as cooperativas, as organizações mutualistas e as organizações sem fins lucrativos (essencialmente associações).

Tentamos definir conceitos e, assim, diferenciar práticas sociais. Mas há autores que vêem uma semelhança entre os processos sociais descritos por esses diversos termos. Segundo Jacques Robin, no livro Vers une économie plurielle, trata-se "de novas dinâmicas que Bernard Ėme e Laville chamam 'economia solidária', e outros, como Alain Lipietz, um 'terceiro setor de utilidade econômica e social', e cuja profusão renova o que foi chamado tradicionalmente de economia social - que agrupa o mundo das cooperativas, das associações e das mutualidades"9 (Aznar et al. 1997: 100-01).

A proliferação das apelações é explicada por Chaves Ávila a partir do fato que o objeto de estudo foi ampliando-se progressivamente, introduzindo ao lado das cooperativas, das mutualidades e do associativismo - trilogia da eco-

${ }^{7}$ Que é muito problemática e não bem aceita.

${ }^{8}$ Agradeço a Nanci Valadares e a Adelia Miglievich pelas observações segundo as quais o termo non-profit deve ser entendido como não exploração da mais-valia e não no sentido de ausência de lucro. Mesmo assim, vejo que os autores adeptos do conceito de economia social não o entendem como sinônimo deste.

9 Tradução própria. Mutualidades ou Mútuas, companhia de seguros ou socorros mútuos. “... de nouvelles dynamiques que Bernard Ème et Laville appellent 'économie solidaire', et d'autres, comme Alain Lipietz, un 'tiers secteur d'utilité économique et sociale', et dont le foisonnement renouvelle ce que l'on a appelé traditionnellement l'économie sociale - qui rassemble le monde des coopératives, des associations et des mutuelles". 
nomia social tradicional - todas as formas de associação que contestam a lógica do desenvolvimento capitalista. Desta maneira, foi ampliando-se o grau de heterogeneidade deste setor e diluíram-se progressivamente suas fronteiras históricas com as do setor público, capitalista e de economia doméstica. Além do mais, novas tradições científicas entraram no estudo destes novos campos científicos redescobertos. "Desde esta perspectiva, no resulta extraño que coexista en la actualidad una multitud de términos en el mundo científico para designar a esta realidad o a partes de la misma, como 'Tercer Sistema', 'Sector asociativo', Sector voluntario', 'Economía de interés general' y tantos otros..." (Chaves 1999: 120). Para este autor, há muitos anos a delimitação do objeto de estudo da economia social suscita um debate acalorado e esta é uma questão essencial, pois tem implicações teóricas ao nível explicativo e preditivo. De fato, as construções teóricas que podem ser feitas sobre as cooperativas de trabalho associado, base do que se considera o setor autogestionário ou cooperativo, diferem daquelas que podem ser elaboradas sobre as fundações e outras organizações voluntárias ou sem fins lucrativos.

Durante a entrevista que me concedeu o professor Jacques Defourny (2001), diretor do Centre d'Études Sociales, em Liège, Bélgica, ele respondeu ao meu questionamento sobre a terminologia usada em diversos países. Confirmaram-se, de maneira concreta, as afirmações de Chaves sobre a ampliação do objeto de estudo e as novas disciplinas que dirigiram suas pesquisas para a economia social ou terceiro setor; ele não pareceu preocupado, no entanto, com a discussão conceitual. Para ele, estando disponível o termo economia social e não se conhecendo outro na Bélgica, é este mesmo que foi utilizado e, mais tarde, quando surgiram outras apelações, uma atitude pragmática levou os estudiosos desta área a manterem o termo histórico de economia social mesmo quando estão falando daquilo que outros podem chamar de economia solidária. Ele e Monzón, no entanto, tomaram a iniciativa de publicar, em 1992, um livro bilíngüe franco-inglês onde o termo economia social foi traduzido por third sector.

A revista Recma, no seu editorial $A$ solidariedade em questão, de janeiro 2001, estabelece uma nítida diferença entre economia social e economia solidária. Primeiro, a solidariedade é problematizada. Etimologicamente, o termo é uma deformação da palavra latina solidum que, entre os jurisconsultos romanos, servia para designar a obrigação que pesava sobre os devedores quando 
cada um era responsável pelo todo (in solidum). A solidariedade, antes de ser um valor, é um fato e designa uma dependência recíproca. Esta concepção faz da solidariedade uma realidade possível de constatar como a definia Durkheim nas suas modalidades mecânica e orgânica. Uma outra concepção, normativa desta vez, faz da solidariedade um dever moral de assistência como já o preconizava o solidarismo de C. Gide no fim do século XIX. Como fato ou como dever, a solidariedade supõe um laço recíproco (e nisso se opõe à caridade, concebida como um dever unilateral). $\mathrm{O}$ dever moral de assistência, mas não a solidariedade como fato, supõe uma situação de desigualdade. Deste ponto de vista, a economia solidária apóia-se sobre uma economia de sujeitos desiguais, enquanto que a economia social é, pelos seus princípios e regras, uma economia de iguais. Se a economia solidária é econômica e socialmente necessária, ela não é suficiente para definir a sociedade igualitária à qual aspira. Por outro lado, a economia social não parece estar em condições de trazer um remédio para o crescimento das desigualdades; mas define experiências de sociedades igualitárias e, sob este ângulo, aparece como o horizonte possível ou provável da economia solidária, uma forma de permitir aos "beneficiários" da solidariedade que assumam sua economia, de maneira voluntária e não dependente. E o editorial termina colocando que estas duas economias podem ser consideradas como complementares e que seus méritos respectivos poderiam reforçar-se mutuamente.

O termo solidariedade pode também ser decomposto a partir de suas formas, que Hegner ${ }^{10}$ (1986) define como de reciprocidade, de lealdade e de altruísmo. Só nos dois primeiros casos, temos uma dependência recíproca de fato. Nestes casos não se comprova a desigualdade entre os pares. A solidariedade só indica que, no momento de sua aplicação, há desigualdade de situação entre aquele que dá e aquele que recebe, mas não indica uma desigualdade intrínseca. Como vou mostrar a seguir, é esse o sentido que o adjetivo "solidária" toma na literatura brasileira.

${ }^{10}$ Encontrei esta referência no texto de Emil Sobottka (2001). 


\section{A noção de economia solidária dos autores brasileiros}

O conceito economia de solidariedade aparece pela primeira vez no Brasil em 1993, ${ }^{11}$ num texto do autor chileno Razeto que o concebe como

uma formulação teórica de nível científico, elaborada a partir e para dar conta de conjuntos significativos de experiências econômicas (...), que compartilham alguns traços constitutivos e essenciais de solidariedade, mutualismo, cooperação e autogestão comunitária, que definem uma racionalidade especial, diferente de outras racionalidades econômicas. (Razeto 1993: 40)

Mas é somente mais tarde que ele vai realmente tomar corpo. Ao meu ver, dois encontros vão constituir um marco para a construção de um pensamento e/ou movimento social em prol da economia solidária no Brasil, apesar de não serem os únicos. $\mathrm{O}$ primeiro aconteceu por ocasião de uma mesa redonda sobre o tema Formas de combate e de resistência à pobreza, realizada em setembro de 1995, durante o $7^{\circ}$ Congresso Nacional da Sociedade Brasileira de Sociologia. O segundo foi o III Encontro Nacional da Associação Nacional dos Trabalhadores em Empresas de Autogestão e Participação Acionária (Anteaf), que teve lugar em São Paulo nos dias 30 e 31 de maio de 1996. Os trabalhos apresentados na mesa redonda do $7^{\circ}$ encontro foram organizados em coletânea por Luiz Inácio Gaiger e publicados em 1996. Na apresentação, o organizador escreve: “A comparação entre essas diversas experiências permite identificar, como tipo promissor e como alternativa viável para a economia popular, os empreendimentos solidários, que reúnem, de forma inovadora, características do espírito empresarial moderno ${ }^{12}$ e princípios do solidarismo e da cooperação econômica apoiados na vivência comunitária" (Gaiger 1996: 11). Por sua vez, no III Encontro da Anteag não se falou em economia solidária, mas no prefácio do livro, redigido em 1998, e que apresenta as falas dos participantes, Paul Singer escreve que "no bojo da crise do trabalho começou a surgir a solução. (...) Algum milagre? Não, mas grande vontade de lutar, muita disposição ao sacrifício e sobretudo muita solidariedade. É deste modo que a economia solidária ressurge no meio da crise do trabalho e se revela uma solução surpreendentemente efetiva" (Singer 1998: XXXI ). Essa proposta de Singer já tinha sido formulada publicamente em julho de 1996 na Folha de São Paulo sob o título Economia solidária contra o desemprego, bem como constava no programa de

${ }^{11}$ O termo terceiro setor é divulgado em 1994 com a publicação de Fernandes Privado, porém público.

12 "Necessidade de qualificar tecnicamente para tocar empreendimentos numa economia centrada na produtividade e na concorrência." (Gaiger 1996: 109) 
governo do Partido dos Trabalhadores por ocasião das eleições municipais na cidade de São Paulo no mesmo ano. ${ }^{13}$ Segundo Mance, propostas similares também tinham sido defendidas pela oposição democrática popular em Curitiba em 1992 e, em 1988, na cidade de Piraquara, Paraná (Mance 1999: 163).

Em dezembro de 1996, Arruda apresentou o texto Globalização e sociedade civil: repensando o cooperativismo no contexto da cidadania ativa, para a Conferência sobre Globalização e Cidadania, organizada pelo Instituto de pesquisa da ONU para o desenvolvimento social. Neste texto ele apresenta o cooperativismo autogestionário e solidário como proposta para um desenvolvimento que "reconstrua o global a partir da diversidade do local e do nacional" (Arruda 1996: 27).

É nesse processo que ganha enorme importância a práxis de um cooperativismo autônomo, autogestionário e solidário, que inova no espaço da empresa-comunidade humana e também na relação de troca entre os diversos agentes; (...) o associativismo e o cooperativismo autogestionários, transformados em projetos estratégicos, podem ser os meios mais adequados para a reestruturação da sócio-economia na nova era que se anuncia. (Arruda 1996: 4)

A percepção desse novo pensamento e/ou movimento social e sua nomeação só foi possível post-factum, quando a repetição dos encontros acadêmicos e militantes tornou cada vez mais nítida a sua realidade. As três propostas elencadas acima, que identifiquei a partir de Gaiger, Singer e Arruda, com suas especificidades e divergências, vão ser reunidas pela primeira vez em 1999, na Universidade Católica do Salvador, por ocasião do seminário Economia dos setores populares: entre a realidade e a utopia e foram publicadas num livro com o mesmo título. Após isto, Paul Singer organizou a obra intitulada A economia solidária no Brasil: a autogestão como resposta ao desemprego, onde mais uma vez os três autores foram reunidos com muitos outros. Antes disto, Paul Singer e Marcos Arruda (em locais diferentes), como outros intelectuais participaram das "oficinas pedagógicas ou culturais" organizadas à noite pela CUT. Estas reuniam trabalhadores desempregados para debater alternativas de geração de emprego e renda, entre as quais dominava o tema da autogestão, da co-gestão e do cooperativismo. Singer e Gaiger foram reunidos pela Rede Interuniversitária de Estudos e Pesquisas sobre o Trabalho (Unitrabalho) para realizar o projeto Economia solidária e autogestionária, em janeiro de 1999. Muitos outros acadêmi-

${ }^{13}$ A proposta era de Paul Singer, mas foi Aloísio Marcadante que a batizou com o nome de economia solidária (Singer 2001). 
cos e atores estão neste campo e outros virão, mas esta exposição é restrita demais para apresentá-los todos.

No Brasil fala-se de economia popular solidária, de socioeconomia solidária, de economia solidária e autogestionada. Mas aparece igualmente, às vezes, o termo economia social, usado alternativamente para economia solidária, como no texto de Neusa Dal Ri e Candido G. Vieitez (1999), da Unesp de Marília. ${ }^{14}$ Há uma preocupação muito forte em atribuir a apelação de solidária somente àqueles empreendimentos onde, de maneira comprovada, além de haver relações de trabalho autogestionárias, solidárias e democráticas entre seus membros, a solidariedade se manifesta em relação à comunidade envolvente, demonstrando assim uma vontade política de transformação das relações sociais e, por conseqüência, da sociedade. Ou seja, empreendimentos onde o trabalhador se apodere de uma cidadania ativa em vista da construção de uma outra cultura econômica e gerencial (Arruda e Quintela 2000: 325). Além disto, estão incorporados ao termo economia apenas os empreendimentos geradores de renda e trabalho ou ligados diretamente a esses como as cooperativas de consumo solidário e as cooperativas de crédito solidário, ou ainda os clubes de troca. Isto elimina todas as associações sem fins lucrativos que não produzem renda para seus sócios, e todas as organizações cooperativas ou não cujo objetivo se limita ao bem-estar dos seus sócios, faltando-lhes a dimensão política de produzir novas relações sociais em vista de uma mudança de sociedade. Vale ressaltar que, apesar desta exigência, a maioria dos autores reconhece que a implantação dos valores de solidariedade está ainda em construção. Aliás, boa parte dos intelectuais combina pesquisa com estimulação de formação de empreendimentos solidários, cursos de formação via sindicatos, organizações de desenvolvimento solidário ${ }^{15} \mathrm{e}$ órgãos do governo, e assessoria a alguns destes empreendimentos. Nas universidades, multiplicam-se as incubadoras de cooperativas populares.

${ }^{14}$ Foi lançado em São Paulo, dia 23 de outubro de 2001, o livro de Ladislau Dowbor intitulado Economia social no Brasil, mas o conceito é tomado no sentido brasileiro de políticas públicas para saúde, a educação e a habitação.

${ }^{15}$ ODSs é uma sigla usada pelo Pacs do Rio de Janeiro que vem substituir com vantagem, neste caso, o termo ONGs. Esse termo é uma definição pela negação e a realidade que rerpresenta tornou-se extremamente heterogênea e problemática após a mudança de política no Brasil o que levou a sigla a um certo desgaste. 


\section{A conceituação brasileira à luz de outras tradições}

É evidente que as condições sócio-econômicas, políticas e culturais brasileiras diferem muito das de outros países, o que condiciona a análise que dela se faz. Devemos também distinguir, por um lado, o que os autores dizem e escrevem e, por outro, a realidade empírica. Gaiger assim se expressa: "o próprio conceito de Economia Solidária carrega em si algo de projeção, algo de desejo. Nós percebemos coisas que nos levam a falar de economia solidária. Nós idealizamos, (...) esses são conceitos ideais. Eles prefiguram, eles devem ter um papel heurístico" (Gaiger 2000a: 179).

As experiências concretas são extremamente heterogêneas, mas podemos agrupá-las em três tipos de empreendimentos solidários: os projetos alternativos formados por pessoas de baixa renda situadas à margem do mercado formal, incluídos os clubes de troca; as cooperativas autogestionárias de trabalho ou de produção (onde encontramos, por exemplo, as cooperativas dos assentados do MST); e as empresas auto ou co-geridas pelos seus trabalhadores oriundos de empresas falidas do mercado formal. As características comuns aos empreendimentos solidários são: a participação coletiva no trabalho e nas decisões de gestão, a posse coletiva dos bens e a repartição das sobras entre os trabalhadores, com eventual constituição de um fundo solidário para a criação de novos empreendimentos solidários.

Encontramos projetos financiados pela Cáritas (Igreja Católica), por ONGs estrangeiras, pela CUT, pelos governos estaduais (como o do Rio Grande do Sul) ou municipais, e por órgãos públicos como a Finep (Programa de Financiamento das Empresas Autogestionárias, lançado em 1996) ou, ainda, por bancos cooperativados, mas trata-se, em geral, de co-financiamentos onde encontramos tanto verbas públicas como da sociedade civil.

Existe um triplo movimento no campo da economia solidária, onde eu agruparia, primeiro, atividades de cunho especificamente intelectual: estudos, cursos e pesquisas com seus respectivos encontros, seminários e publicações acadêmicas e, em segundo lugar, atividades de formação, promoção e apoio, como financiamentos e assessorias para fomento ou consolidação de cooperativas populares e, num patamar seguinte, a organização e reunião destes empreendimentos em encontros, feiras, clubes, centrais, fóruns (locais, regionais etc.) e redes, na maioria delas hoje com suporte eletrônico. Temos também a criação ou 
proposta de criação de meios e entidades de apoio à economia solidária ao nível nacional e internacional ${ }^{16}$ para elaboração de uma legislação apropriada, de marcas ou etiquetas para marketing, acesso ao crédito, formação e qualificação, moedas alternativas etc.

Apesar destas diferenças, podem ser feitas algumas considerações gerais. Assim, a observação genérica de Laville e Roustang (1999), segundo a qual o conceito de economia solidária proporciona uma ênfase sobre o desejo de evitar o fosso entre o econômico, o social e o político, contempla o entendimento que autores brasileiros têm do mesmo. E isto é, para mim, um ponto de partida, pois tem por efeito que a economia solidária brasileira faz parte do que os francófonos chamam de économie sociale ou solidaire, mas a recíproca não é verdade. A diferença situa-se nos conteúdos semânticos dos termos economia, social e político, usados pelos primeiros num sentido amplo e pelos segundos com um significado muito específico.

Para Laville e seu grupo, a economia é composta de diversos setores, economia de mercado, de não-mercado e não-monetária; nesta concepção, trabalhos voluntários fazem parte da economia solidária. Na literatura brasileira há uma tendência a excluir o voluntariado da economia solidária, bem como toda atividade que não tiver uma finalidade direta de geração de renda (Gaiger 1998). Assim, trabalhos voluntários de alfabetização ou de saúde comunitária não fariam parte, em princípio, dos empreendimentos econômicos solidários. Este último conceito, divulgado por Gaiger - mas construído em relação com outros autores e usado na pesquisa nacional da Unitrabalho - refere-se a empreendimentos

que têm as seguintes características: primeiramente, combinam a busca de eficiência e viabilidade com o aprimoramento dos princípios cooperativos e democráticos; combinam, por outro lado, sua autonomia de gestão com uma atitude de responsabilidade e de envolvimento social; por fim, conjugam a obtenção de resultados econômicos com outros benefícios, no plano da educação, da qualificação profissional, da cultura e assim por diante. (Gaiger 2000a: 177 - grifo meu)

${ }^{16}$ Os seminários de Economia Solidária realizados no I e no II Fórum Social Mundial viram surgir várias propostas como um Banco Social mundial, uma Organização Mundial do Comércio Justo e um Fundo Solidário Internacional. 
Por outro lado, afirma também que "empreendimentos econômicos solidários combinam o espírito empresarial ${ }^{17}$ e o espírito solidário se diferenciam da racionalidade capitalista e da solidariedade comunitária" (Gaiger 1996: 114). Essa nova economia em construção é vista como uma nova forma social de produção "uma forma (determinada) de relações mútuas entre os homens no processo de apropriação da natureza, relações mútuas determinadas pelo lugar que os indivíduos ocupam frente às condições e aos resultados dos diversos processos de trabalho e pelas funções que assumem nesse processo" (Godelier apud Gaiger 1996: 116).

Uma outra distinção refere-se à compreensão do termo social, mas aqui não há unanimidade entre os autores, pois, se a maioria acrescenta o adjetivo popular aos termos de economia solidária, não é, por exemplo, o caso de Paul Singer, nem de Marcos Arruda. Travam-se debates teóricos quanto ao significado de popular, quais os setores da população que seriam compreendidos por esta categoria, quais os critérios para definir quem faz parte deles. Singer (2000: 143) expressou-se da maneira seguinte: "A minha grande dificuldade conceitual, (...) é a Economia Popular". Referindo-se à convenção de Kraychete, segundo a qual a economia dos setores populares designa "as formas de reprodução da vida que não se situam estritamente na lógica da economia capitalista" (2000: 144), Singer objeta que se trata de uma definição pela negação. "É difícil, é complicado tentar entender algo meramente pelo fato de não ser uma outra coisa; é muito vago" (idem). Para ele, a expressão setores populares tem um significado histórico. Há trinta anos que estes termos designam classes de baixa renda, o que não é a mesma coisa do que assalariados - como Corragio o fez entender -, pois entre estes últimos encontram-se também dirigentes das grandes empresas capitalistas. A proposta de Singer, então, é que uma economia não capitalista é uma economia caracterizada basicamente por princípios socialistas ou cooperativistas. ${ }^{18}$ Aqui também o cunho da geração de renda está presente, pois ele escreve: "são empresas igualitárias, em que a posse da empresa é de todos os que trabalham nela, por igual".

Com isto chegamos ao político. Para considerar os empreendimentos como solidários, esses autores não estão falando de filantropia, bem pelo contrário:

17 "Necessidade de qualificar tecnicamente para tocar empreendimentos numa economia centrada na produtividade e na concorrência." (Gaiger 1996: 109)

${ }^{18}$ E aqui Singer afirma a identidade dos termos, referindo-se a Marx e Lenin para provar isto. 
trata-se de empresas democráticas "em que todos que nela[s] trabalham têm o mesmo poder de decisão" (Singer 2000: 150), "combinam sua autonomia de gestão com uma atitude de responsabilidade e de envolvimento social" (Gaiger 2000a: 177). Para que haja autonomia, Gaiger preconiza a substituição de financiamento a fundo perdido pela obrigatoriedade de devolução, o que instaura uma reciprocidade possível, passo indispensável para a autonomia (Gaiger 1996: 122). Assim, desde 1996, Gaiger faz a distinção entre projetos concebidos como parte de uma proposta política e projetos às voltas com a sobrevivência imediata, só os primeiros sendo identificados como empreendimentos promissores para a construção de uma economia popular solidária. $\mathrm{O}$ exemplo proposto é a produção coletiva nos assentamentos rurais do Movimento dos Trabalhadores sem Terra, “esses são 'modelo' do que é visado, indicam algo sobre as potencialidades" (Gaiger 1996: 105). Em resposta às críticas de certos intelectuais como Clêyde Souza, Gaiger (1996: 103) coloca que não seriam uma coisa (amenizar a pobreza) ou outra (mobilização e organização popular), mas que uma é condição da outra.

\section{Em resumo}

Ao que tudo indica, não há uma definição clara hoje do que seria terceiro setor, economia social ou economia solidária, sem entrar no detalhe de muitas outras nomenclaturas. Podemos também observar uma aproximação progressiva entre o terceiro setor e o setor público, com o qual realiza parcerias ${ }^{19}$ cada vez mais numerosas e, em certos casos, uma aproximação da economia solidária com a economia doméstica. As fronteiras são cada vez mais reafirmadas, isso sim, no caso da economia solidária em relação ao projeto de desenvolvimento capitalista neoliberal.

Não se pode dizer que a economia solidária não faça parte da economia social no sentido que este termo tem atual e historicamente na Europa, ou seja, como uma iniciativa das classes trabalhadoras contra a miséria e o desemprego. Agora, as coisas se complicam quando o termo economia social é traduzido, como o faz Defourny, por terceiro setor. Concordo com Chaves que há um problema real em colocar sob a mesma denominação coisas tão heterogêneas quanto a filantropia das empresas capitalistas e uma empresa autogerida pelos própri-

${ }^{19}$ Autores como por exemplo Mance, no entanto, discordam sobre o fato de o apoio do estado ser uma condição sine qua non para a sobrevivência da economia solidária (Mance 1999: 171). 
os trabalhadores; isto tem implicações teóricas ao nível explicativo e de predição. Uma das diferenças é que as primeiras - como todos os serviços voluntários - preenchem lacunas do sistema capitalista, enquanto que as segundas emulam suas congêneres capitalistas e competem com elas.

É necessária uma reformulação das categorias de análise. E, apesar das indefinições atuais da terminologia brasileira, o conceito de empreendimento econômico solidário tem suas vantagens pela afirmação positiva que contém. É preciso fazer a construção crítica do conceito de terceiro setor e da realidade que este conceito procuraria expressar na visão de quem o formulou. Ele precisa ser revisto ou até substituído para que os estudos possam ganhar mais precisão e eficácia analítica.

De maneira contraditória, o estreitamento de significações que faz a força do conceito de economia solidária no Brasil vem acompanhado de certas limitações criadas pela ausência quase generalizada do resgate histórico anterior aos anos 1980 (com exceção de Singer 2002), pela pouca ênfase dada à pluralidade ideológica e ao hibridismo econômico. Ele se distingue também do conceito europeu e quebequense quanto à expectativa do papel futuro desta economia para a transformação da sociedade. Pode-se dizer que há, hoje, no Brasil, uma preocupação militante em relação à formação e à qualificação de empreendimentos solidários, à formação de redes e à tentativa de persuasão dos $\operatorname{sindicatos}^{20} \mathrm{e}$ da esquerda quanto ao papel estratégico do projeto de economia solidária na luta contra o sistema capitalista, contra o neoliberalismo e por uma nova sociedade. Talvez este ativismo seja responsável pela atual indefinição no campo conceitual e teórico.

O editorial da revista Recma traz uma contribuição que me parece fundamental. "Como fato ou como dever, a solidariedade supõe um laço recíproco (e se opõe nisso à caridade, concebida como um dever unilateral)". Aqui temos um divisor importante e uma ferramenta de pesquisa. O que está sendo refutado pelos intelectuais brasileiros da economia solidária é a possibilidade de introduzir nesta categoria práticas em sentido único e entre desiguais, senão de fato pelo menos de direito. Por esta razão, a economia solidária como é definida no Brasil não pode ser arrolada nas fileiras do setor voluntário, muito menos nas "charities". Mas o editorial termina colocando que as economias social e solidária podem ser consideradas como complementares e que seus méritos respectivos po-

${ }^{20}$ Estes já foram, em grande parte, conquistados. 
deriam reforçar-se mutuamente. Penso que isto será matéria de reflexão e assunto para outras pesquisas.

\section{Referências bibliográficas}

Arruda, Marcos (2000). Globalização e sociedade civil: repensando o cooperativismo no contexto da cidadania ativa. [Conferência sobre globalização e cidadania, organizado pelo Instituto de pesquisa da ONU para o desenvolvimento social.] In: Marcos Arruda; Leonardo Boff. Globalização: desafios socioeconômicos, éticos e educativos: uma visão a partir do Sul. Petrópolis: Vozes, p. 49-102 [originalmente 12/1996, revisto em 99$]$.

; Quintela, Sandra (2000). Economia a partir do coração. In: Paul Singer; André Ricardo de Souza (orgs). A economia solidária no Brasil: a autogestão como resposta ao desemprego. São Paulo: Contexto, p. 317-332.

Aznar, Guy et al. (1997). Vers une économie plurielle. Paris: Syros.

Ceas (1994). A chamada economia popular em debate. Cadernos do Ceas, n. 153, p. 5969 , set.-out.

Chaves Ávila, Rafael (1999). La economía social como enfoque metodológico, como objeto de estudio y como disciplina científica. Ciriec-España, n. 33, p. 116-139.

Dal Ri, Neusa M.; Vieitez, Candido Giraldez (1999). A economia solidária e o desafio da democratização das relações de trabalho no Brasil. In: —_ . (org.). Economia solidária: o desafio da democratização das relações de trabalho. São Paulo: Arte \& Ciência, p. 11-42.

Defourny, Jacques (2001). Entrevista concedida a Noëlle Lechat pelo Diretor do Centre d'Études Sociales. Liège, Bélgica, 15 jun.

; Monzón, J. L. (1992). Économie sociale: the third setor: entre économie capitaliste et économie publique. Bruxelles: De Boeck.

Defourny, Jacques et al. (1999). Le fil conducteur de l'ouvrage: enjeux et chantiers de l'économie sociale. In: —_ Économie sociale au Nord et au Sud. Bruxelles: Deboeck, p. 11-24.

Fernandes, Rubem César (1994). Privado, porém público: o terceiro setor na América Latina. Rio de Janeiro: Relume-Dumará.

Gaiger, Luiz Inácio (1996). Empreendimentos solidários: uma alternativa para a economia popular? In: - . . (org.). Formas de combate e de resistência à pobreza. São Leopoldo: Unisinos, p. 101-126.

. (1998). A solidariedade como alternativa econômica para os pobres. Contexto e Educação, n. 50, p. 47-71. 
. (2000a). Sentidos e possibilidades da economia solidária hoje. In: Gabriel Kraychete et al. (orgs.) Economia dos setores populares. Petrópolis: Vozes (Capina/Cese/UCSal), p. 167-198.

. (2000b). A economia popular solidária no horizonte do terceiro setor. Dublin: ITR'S Fourth international conference, jul.

. (2000c). Os caminhos da economia solidária no Rio Grande do Sul. In: Paul Singer; André Ricardo de Souza (orgs.). A economia solidária no Brasil: a autogestão como resposta ao desemprego. São Paulo: Contexto, p. 267- 286.

Guélin, André (1998). L'invention de l'économie sociale. Paris: Econômica.

Larrachea, Ignácio; Nyssens, Marthe (1994). L'économie solidaire, un autre regard sur l'économie populaire au Chili. In: Jean-Louis Laville (dir.). L'économie solidaire. Paris: Desclée de Brouwer. p. 177-222.

La solidarité en question(s). Recma, v. 80, n. 279, jan. 2001.

Laville, Jean-Louis (dir.) (1994). L'économie solidaire. Paris: Desclée de Brouwer.

; Roustang, Guy (1999). L'enjeu d'un partenariat entre État et société civile. In: Jacques Defourny et al. Economie sociale au Nord et au Sud. Bruxelles: Deboeck, p. 217-238.

Lévesque, Benoît et al. (1997). La sociologie économique de langue française. Cahiers internationaux de sociologie, v. 103, p. 265-294.

; (1999). L'ancienne et la nouvelle économie sociale. In: Jacques Defourny et al. Economie sociale au Nord et au Sud. Bruxelles: Deboeck, p. 195-216.

Mance, E. A. (1999). A revolução das redes: a colaboração solidária como uma alternativa pós-capitalista à globalização atual. Petrópolis: Vozes.

Nyssens, Marthe. (1996). Economie populaire au Sud, économie sociale au Nord. In: Ocde. Réconcilier l'économique et le social. Vers une économie plurielle. Paris, p. 95-120.

Razeto, Luís (1993). Economia de solidariedade e organização popular. In: Moacir Gadotti (org.). Educação comunitária e economia popular. São Paulo: Cortez, p. 34-58.

Sarria Icaza, Ana Mercedes (2000). Tercer sector y economía solidaria en el Sur de Brasil: características y perspectivas. Dublin, jul.

Singer, Paul (1998). Prefácio. In: ANTEAG. Empresa social e globalização: Administração autogestionária: uma possibilidade de trabalho permanente. São Paulo: ANTEAG. . (2000). Economia dos setores populares: propostas e desafios. In: Gabriel Kraychete et al. (orgs.). Economia dos setores populares: entre a realidade e a utopia. Petrópolis: Vozes (Capina/Cese/UCSal), p. 143-165. 
. (2002). Introdução à economia solidária. São Paulo: Perseu Abramo.

Sobottka, Emil (2001). Organizações civis: buscando uma definição para além de ONGs e "terceiro setor". XI Congresso Estadual de Sociólogos do Estado de São Paulo, São Paulo, 1-4 out. [Civitas, v. 2, n. 1, jun. 2002]. 